DOI:https://doi.org/10.31933/dijemss.v2i2 Received: 19 September 2020, Revised: 25 October 2020, Publish: 19 Desember 2020

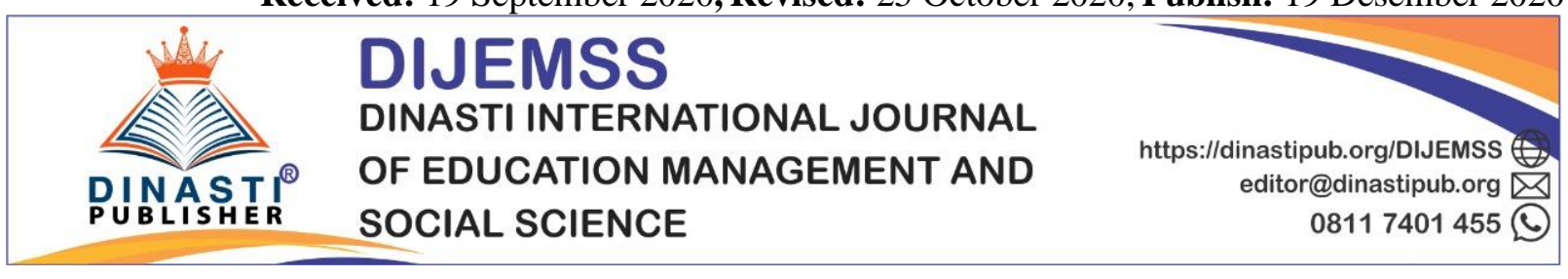

\title{
THE IMPACT OF BRAND IMAGE, SALES PROMOTION, SERVICE QUALITY TOWARDS CUSTOMER SATISFACTION AND ITS IMPLICATIONS ON CUSTOMER LOYALTY AT X DEPARTMENT STORE KOTA KASABLANKA JAKARTA
}

\author{
Adityo Jati Prabowo ${ }^{1}$, Arifin Sitio ${ }^{2}$ \\ 1) Mercu Buana University, Jakarta, Indonesia, adityo.jepe@gmail.com \\ 2) Mercu Buana University, Jakarta, Indonesia \\ Corresponding Author: Adityo Jati Prabowo
}

\begin{abstract}
This research had goal to discover those impact from Brand Image, Sales Promotion, Service Quality on Customer Loyalty with Customer Satisfaction as intervening variable which occured at X Department Store Kota Kasablanka Jakarta. The number of respondents was 100 respondents which obtained by simple random sampling technique. This research used path analysis with assist of IBM SPSS Statistics version 25 program. The results had shown that brand image, sales promotion, service quality had significant positive impact on customer loyalty by customer satisfaction as intervening variable at X Department Store in Kota Kasablanka Jakarta.
\end{abstract}

Keywords: Brand Image, Sales Promotion, Service Quality, Customer Satisfaction, Customer Loyalty.

\section{INTRODUCTION}

In the business/trade world that faced with intense and sharp competition among economic actors, beside that the business world did not always survive in compete with times that change rapidly and also with growth fast of innovation. Retail is one of the fields that engaged in economic trading which collects those various kinds of goods from so many sources, buys in large quantities and sells in small quantities.

According to the Central Statistics Agency (BPS), Indonesia's economy in the third quarter of 2019 was grew of 5.02 percent (year on year), and according to Indonesian Retail Entrepreneurs Association (Aprindo), retail transactions in 2019 were estimated to increase by double digits for the first time in five years. (2014 s / d 2019). The total value of the transaction topped Rp. 258 trillion. Other than that ,by Aprindo's prediction which told that until 2019 there will be an increase in retail transaction records, this has proven positive by the results from sales report of PT. X. There had store located in Jakarta which had experienced a significant YoY growth compared to other stores that located in Jakarta. 
The increase ratio in one of these stores was up to $7.30 \%$ in first year and $9.10 \%$ in second year compared to the average growth of other stores in Jakarta which is only $3.03 \%$ in first year and $3.43 \%$ in second year. From the author's observations based on processed data result, the KK shops had experienced a significant increase in sales compared to other stores which located in Jakarta. This makes the author want to know further whether there has difference which makes visitors from the KK shop was capable to earned significant sales so the ratio from comparison ratio had increased significantly to other stores in Jakarta.

Table 1. Sales Increase Ratio from PT. X in Jakarta 2017-2019

\begin{tabular}{ccc}
\hline \multirow{2}{*}{ Store Name } & \multicolumn{2}{c}{ Year } \\
\cline { 2 - 3 } & $\mathbf{2 0 1 7 - 2 0 1 8}$ & $\mathbf{2 0 1 8}-\mathbf{2 0 1 9}$ \\
\hline PM & $2.10 \%$ & $1.40 \%$ \\
PS & $3.20 \%$ & $4.20 \%$ \\
KG & $2.00 \%$ & $3.40 \%$ \\
KK & $7.30 \%$ & $9.10 \%$ \\
CP & $2.10 \%$ & $1.20 \%$ \\
EP & $1.50 \%$ & $1.30 \%$ \\
\hline
\end{tabular}

Based on these pre-research result, it was known that in department store there were several factors that affects the customer satisfaction and loyalty, such as brand image, sales promotion, and service quality. Relate to these matter, the authors put this problem as research with title "The Impact of Brand Image, Sales Promotion, Service Quality towards Customer Satisfaction and its Implications on Customer Loyalty at X Department Store Kota Kasablanka Jakarta".

\section{LITERATURE REVIEW Brand Image}

According to Kotler and Armstrong (2014:286) brand image is the perception and belief which held by consumers, as reflected with associations stored in consumer's minds. The shaped from positive brand image will attract the targeted buyers to buy a particular brand and keep them to coming back. (Rath \& Bay, 2015:28).

\section{Sales Promotion}

According to Simamora in Ali, et al (2018) promotion is any form of communication used to inform, persuade or remind people about products that produced by organizations, individuals, or households. Kotler and Armstrong (2014: 396) has explained that sales promotion is a short-term impulse to encourage the purchase or sale of a product or service. While Kotler and Keller (2016:519) was explained if the sales promotion is a main material from marketing campaign that consist of gathered incentive tools.

\section{Service Quality}

According to Yazid in Kurniawan, et al (2020) customer satisfaction is the absence of difference between the expectations that owned mind and the performance which actually received. Furthermore, Kotler and Armstrong in Gunawan and Prasetyo (2020) said that 
customers form expectations about the value and satisfaction that would be provided from various market offerings and buy based on these expectations.

\section{Customer Loyalty}

According to Kotler and Keller in Tiasanty and Sitip (2019), loyalty was defined as a strong commitment to buy or subscribe to certain products or services in the future. Furthermore, based on Griffin in Tiasanty and Sitip (2019), loyal customers would have these characteristics, such as making regular repurchase, buying between product / service lines, referring to others and having immunity to attract the other products / services.

\section{Theoretical Framework}

The theoretical framework in these research could be explained as follows:

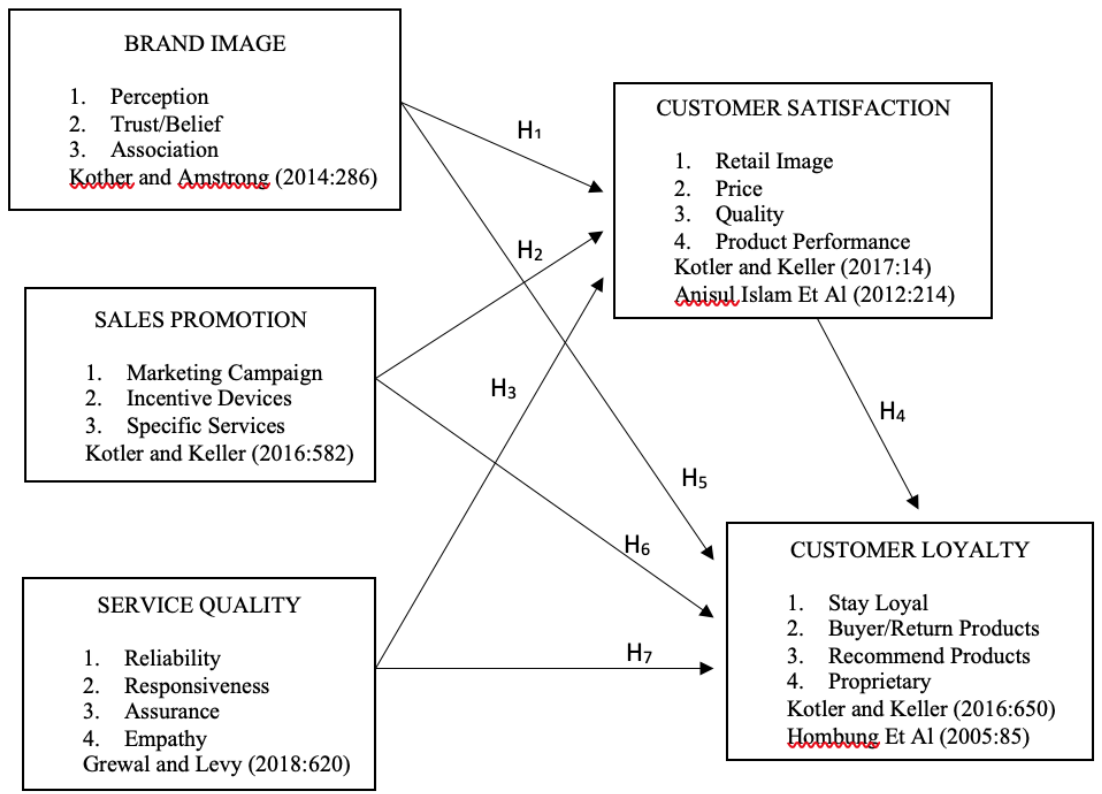

Figure 1.Theoretical Framework

\section{Hypothesis}

Based on these theoretical framework which stated above, the following hypothesis could be taken such as:

1) It is suspected that there had positive and significant influence from brand image on customer satisfaction.

2) It is suspected that there had positive and significant impact of sales promotion on customer satisfaction.

3) It is suspected that there had positive and significant impact from service quality on customer satisfaction.

4) It is suspected that there had positive and significant impact of customer satisfaction on customer loyalty.

5) It is suspected that there had positive and significant influence from brand image on customer loyalty by customer satisfaction as an intervening variable. 
6) It is suspected that there had positive and significant impact from sales promotion on customer loyalty by customer satisfaction as an intervening variable.

7) It is suspected that there had positive and significant impact of service quality on customer loyalty with customer satisfaction as an intervening variable.

\section{RESEARH METHODS}

The method used in this research was descriptive analysis method with quantitative approach which aims to systematically and factually describe the facts that the relationships between the variables which investigated by collecting data, processing, analyzing, and interpreting the data in statistical hypothesis test. The variables used in this research were Brand Image (X1), Sales Promotion (X2), Service Quality (X3), Customer Satisfaction (Y) and Customer Loyalty (Z). In these research the population is all customers who shop at $\mathrm{X}$ Department Stor Kota Kasablanka Jakarta. According to Frankel and Wallen (1993: 92), the minimum sample size is suggested for: (1) 100 descriptive research; (2) 50 correlational research (3) The comparative causal research was $30 /$ group (4) The experimental research was 30/15 per group. In according to the research design, which is descriptive analysis with quantitative approach, the number of respondents which taken as a sample was 100 customers from population. Thus the sampling technique used was simple random sampling method. This research used path analysis with assist of IBM SPSS Statistics version 25 program to examined these hypothesis.

\section{RESULT AND DISCUSSION Respondent Characteristics}

Based on characteristics from 100 respondents who are customers of the X Department Store Kota Kasablanka Jakarta, it could be describe that the majority of customers were women (60\%) aged between 31-40 years (47\%) who had Bachelor education (45\%) and have jobs as private employees (25\%)which earned between IDR 10,000,001-IDR 15,000,000 (40\%). So it could be concluded that the customers from X Department Store Kota Kasablanka Jakarta were career women who have a high fashion sense and want to look attractive to support them in their daily activities.

\section{Validity and Reliability Test}

Based on these validity test, it was known that all research indicators had rcount value $>r$ table (0.196), then it could be concluded that all indicators in these variables from brand image, sales promotion, service quality, customer satisfaction and customer loyalty were declared valid.

Table 2. Validity Test Results

\begin{tabular}{ccccccccccc}
\hline No. & $\mathrm{r}_{\text {count }} \mathrm{X}_{1}$ & Info & $\mathrm{r}_{\text {count }} \mathrm{X}_{2}$ & Info & $\mathrm{r}_{\text {count }} \mathrm{X}_{3}$ & Info & $\mathrm{r}_{\text {count }} \mathrm{Y}$ & Info & $\mathrm{r}_{\text {count }} \mathrm{Z}$ & Info \\
\hline 1 & 0.854 & Valid & 0.972 & Valid & 0.967 & Valid & 0.821 & Valid & 0.809 & Valid \\
2 & 0.842 & Valid & 0.957 & Valid & 0.958 & Valid & 0.870 & Valid & 0.983 & Valid \\
3 & 0.864 & Valid & 0.980 & Valid & 0.891 & Valid & 0.822 & Valid & 0.983 & Valid \\
4 & & & & & 0.960 & Valid & 0.800 & Valid & 0.986 & Valid \\
5 & & & & & 0.885 & Valid & & & 0.986 & Valid \\
\hline
\end{tabular}


Based on these reliability test result, it was known that all the variables which tested (brand image, sales promotion, service quality, customer satisfaction and customer loyalty) were reliable because all variables had Cronbanch's Alpha value > 0.60.

Table 3. Reliability Test Results

\begin{tabular}{lcc}
\hline \multicolumn{1}{c}{ Variable } & Cronbanch's Alpha & Conclusion \\
\hline Brand Image & 0.813 & Reliable \\
Sales Promotion & 0.968 & Reliable \\
Service Quality & 0.960 & Reliable \\
Customer Satisfaction & 0.847 & Reliable \\
Customer Loyalty & 0.974 & Reliable \\
\hline
\end{tabular}

\section{Classic Assumption Test}

Based on these normality test results it could be said that these data was normally distributed. This because the Asymp Sig. value (2-tailed) of 0.200 or greater than 0.05 .

Table 4. Normality Test Results One-Sample Kolmogorov-Smirnov Test

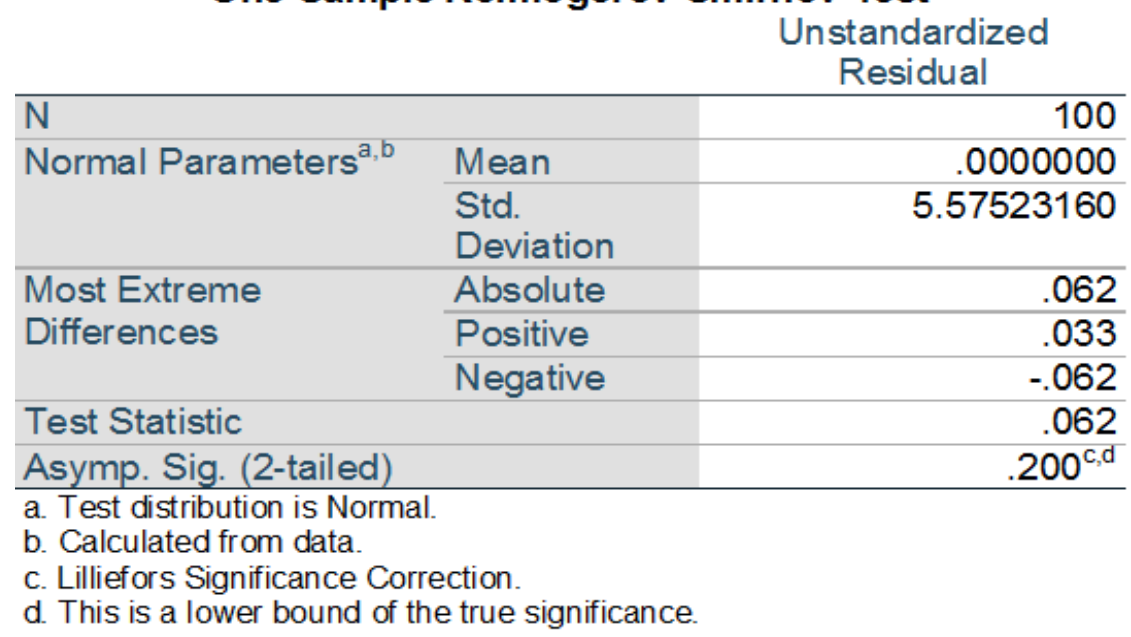

Based on these multicollinearity test results, it could be described that the tolerance value $<1$, and VIF value $<10$. This shows that the independent / free variables in this research were not correlated or there has no correlation between these independent variables, so the model did not contain multicolonierity.

Table 5. Multicollinearal Test Results

\begin{tabular}{lccl}
\hline \multicolumn{1}{c}{ Variable } & Tolerance & VIF & Conclusion \\
\hline Brand Image & 0,789 & 1,268 & There had no multicollinearity \\
Sales Promotion & 0,783 & 1,277 & There had no multicollinearity \\
Service Quality & 0,438 & 2,285 & There had no multicollinearity \\
Customer Satisfaction & 0,470 & 2,128 & There had no multicollinearity \\
\hline
\end{tabular}


Based on these heteroscedasticity test results by scatterplot diagram, it could be seen that the dots spread randomly and spread either above or below the 0 (zero) number on the $\mathrm{Y}$ axis then it could be said if there had no heteroscedasticity in these regression model.

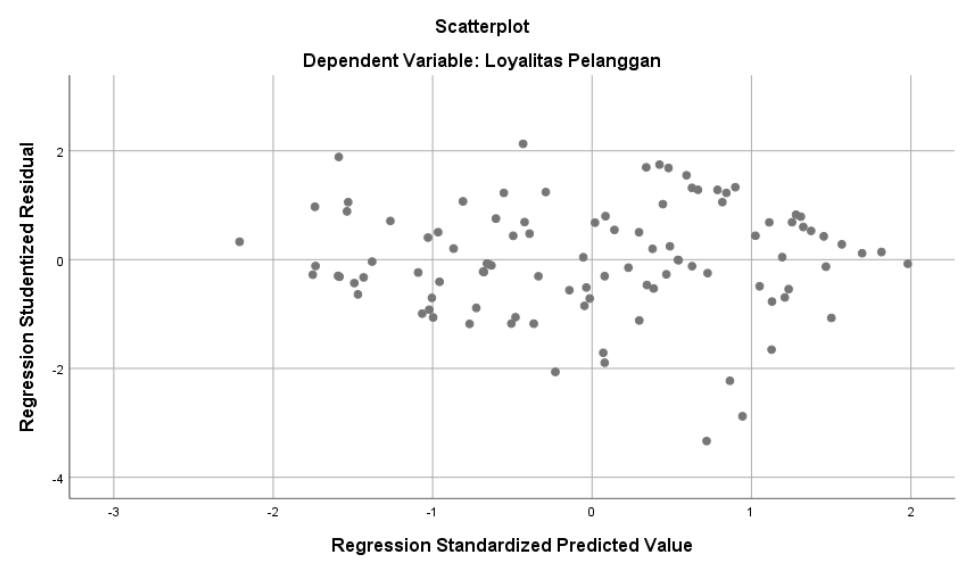

Figure 2. Heteroscedasticity Test Results

\section{Hypothesis Examination}

Based on these hypothesis test result, it was known that the $t$ value from brand image variable was 0.726 < the t-table which specified with Sig. $>0.05$, so it could be said that brand image had no impact on customer satisfaction. The t-value from sales promotion variable was 0.911 the t-table which specified with Sig. > 0.05, so it could be said that sales promotions had no impact on customer satisfaction. The t-value from service quality variable was $8.291>$ t-table which specified and Sig. $<0.05$, so it can be said that service quality had positive and significant influence on customer satisfaction.

\begin{tabular}{|c|c|c|c|c|c|c|}
\hline & & Table 6 & Regression M & odel 1 & & \\
\hline & & $\begin{array}{l}\text { Unstanc } \\
\text { Coeffi }\end{array}$ & $\begin{array}{l}\text { ardized } \\
\text { cients }\end{array}$ & $\begin{array}{c}\text { Standardized } \\
\text { Coefficients }\end{array}$ & & \\
\hline & & $\mathrm{B}$ & Std. Error & Beta & $t$ & Sig. \\
\hline$\overline{1}$ & (Constant) & 14.373 & 2.172 & & 6.618 & .000 \\
\hline & Brand Image & .071 & .098 & .057 & .726 & .470 \\
\hline & $\begin{array}{l}\text { Sales } \\
\text { Promotion }\end{array}$ & .081 & .089 & .072 & .911 & .365 \\
\hline & Service Quality & .366 & .044 & 669 & 8.291 & .000 \\
\hline
\end{tabular}

a. Dependent Variable: Customer Satisfaction

Based on these hypothesis test result, it was known that the $t$ value from brand image variable was $3.128>$ the $\mathrm{t}$-table which specified with Sig. $<0.05$, so it can be said that brand image had positive and significant impact on customer loyalty. The t-value in sales promotion variable was $3.123>$ t-table which specified with Sig. value $<0.05$, so it could be said that sales promotions had positive and significant impact on customer loyalty. The t-value from service quality variable was $3.141>$ the t-table which specified with Sig. $<0.05$, so it could be said that service quality had positive and significant impact on customer loyalty. The t-value from customer satisfaction variable was $3.121>$ t-table which specified by Sig. value $<0.05$, so it could be concluded that customer satisfaction had positive and significant impact on customer loyalty. 
Table 7. Regression Model 2

\begin{tabular}{|c|c|c|c|c|c|}
\hline \multirow[b]{2}{*}{ Model } & \multicolumn{2}{|c|}{$\begin{array}{c}\text { Unstandardized } \\
\text { Coefficients }\end{array}$} & \multirow{2}{*}{$\begin{array}{c}\text { Standardized } \\
\text { Coefficients } \\
\text { Beta }\end{array}$} & \multirow[b]{2}{*}{$t$} & \multirow[b]{2}{*}{ Sig. } \\
\hline & $\mathrm{B}$ & Std. Error & & & \\
\hline 1 (Constant) & -16.889 & 4.886 & & -3.457 & .001 \\
\hline Brand Image & .574 & .184 & .221 & 3.128 & .002 \\
\hline Sales Promotion & .522 & .167 & .222 & 3.123 & .002 \\
\hline Service Quality & .339 & .108 & .298 & 3.141 & .002 \\
\hline Customer Satisfaction & .594 & .190 & .286 & 3.121 & .002 \\
\hline
\end{tabular}

a. Dependent Variable: Customer Loyalty

The first regression analysis was to find out the strength from the relations between independent variable (independent) to mediating variable (intervening). The second regression analysis was to discover those strength from independent variable to dependent variable.

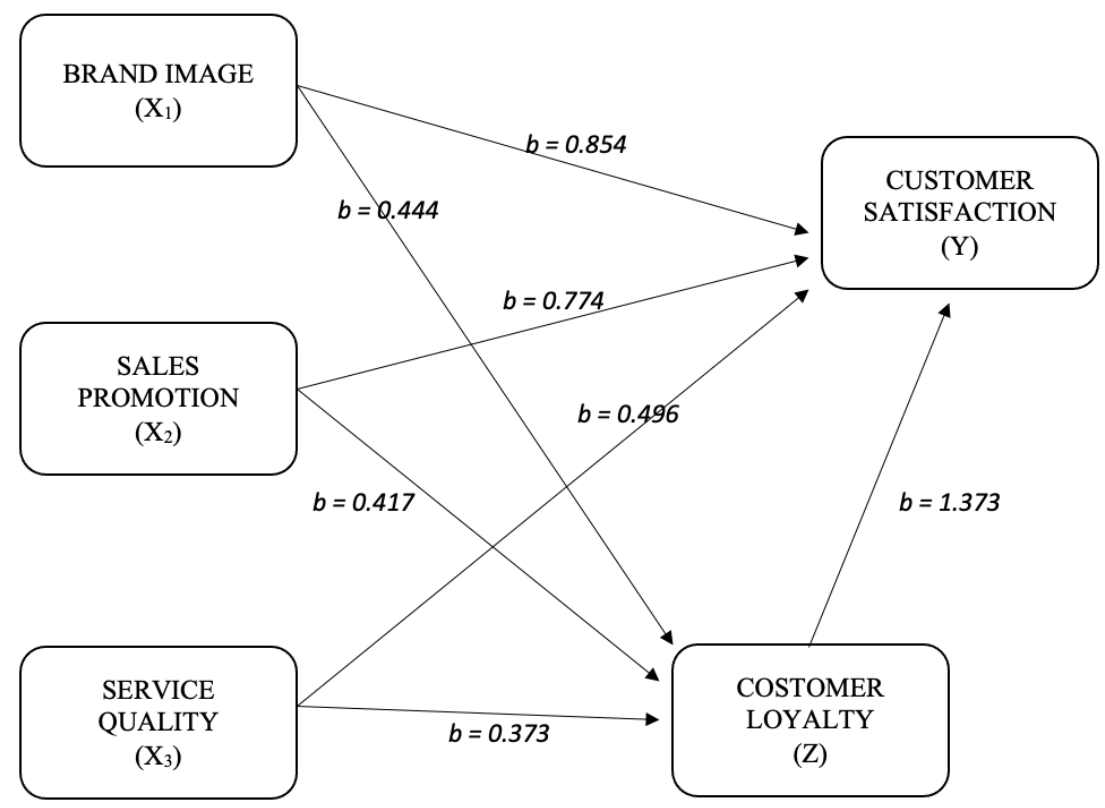

Figure 3. The Interpretation of Path Analysis

\section{Analysis of Indirect Effect and Total Effect}

1) Analysis related to those influence from brand image on customer loyalty through customer satisfaction. The indirect effect of brand image on customer loyalty through customer satisfaction was $0.071 \times 0.594=0.042$ with total effect was 1,428 .

2) Analysis related to those influence from sales promotions to customer loyalty through customer satisfaction. The indirect effect of sales promotions on customer loyalty through customer satisfaction was $0.081 \times 0.594=0.0481$ with total effect of 1.296.

3) Analysis related to those influence from service quality on customer loyalty through customer satisfaction. The indirect effect of sales promotions on customer loyalty through customer satisfaction was $0.366 \times 0.594=0.2174$ with total effect of 0.835 . 
Table 8. Analysis of Indirect Effect and Total Effect

\begin{tabular}{clccc}
\hline No. & \multicolumn{1}{c}{ Variable } & Direct & Indirect & Total \\
\hline 1 & Brand Image & 0.574 & $0.071 \times 0.594=0.0421$ & 1.428 \\
2 & Sales Promotion & 0.522 & $0.081 \times 0.594=0.0481$ & 1.296 \\
3 & Service Quality & 0.339 & $0.366 \times 0.594=0.2174$ & 0.835 \\
\hline
\end{tabular}

\section{Analysis of Correlation Between Dimension}

As for these results based on this research are:

Table 9. Dimension Correlation Matrix on Customer Satisfaction

\begin{tabular}{|c|c|c|c|c|c|}
\hline \multirow[b]{2}{*}{$\mathrm{X}$ Variable } & \multirow[b]{2}{*}{ Dimension } & \multicolumn{4}{|c|}{ Y Variable } \\
\hline & & $\begin{array}{c}\text { Retail } \\
\text { Image (Y.1) }\end{array}$ & Price (Y.2) & $\begin{array}{l}\text { Quality } \\
\text { (Y.3) }\end{array}$ & $\begin{array}{c}\text { B rand Image } \\
(Y .4)\end{array}$ \\
\hline \multirow{3}{*}{ B rand Image (X1) } & Perception (X1.1) & $.221^{*}$ & $.243^{*}$ & $.248^{*}$ & .141 \\
\hline & Trust (X1.2) & $.315^{* *}$ & $.426 * *$ & $378 * *$ & $.279 * *$ \\
\hline & Association (X1.3) & $.234 *$ & $.213^{*}$ & $.224 *$ & .114 \\
\hline \multirow{3}{*}{$\begin{array}{l}\text { Sales Promotion } \\
\text { (X2) }\end{array}$} & Sales Campaign (X2.1) & $.341 * *$ & $362 * *$ & $390 * *$ & $.179 * *$ \\
\hline & Incentive Tools (X2.2) & $.258^{* * *}$ & $314^{* * *}$ & $333 * *$ & $.099 * *$ \\
\hline & Certain Services (X2.3) & $357^{* * *}$ & $357^{* * *}$ & $382 * *$ & $.168 * *$ \\
\hline \multirow{5}{*}{$\begin{array}{l}\text { Service Quality } \\
\text { (X3) }\end{array}$} & Reliability (X3.1) & $.641^{* * *}$ & $.577^{* * *}$ & $.570 * *$ & $.631^{* *}$ \\
\hline & Responsiveness (X3.2) & $.622^{* *}$ & $.554^{* * *}$ & $.552^{* * *}$ & $.629 * *$ \\
\hline & Assurance (X3 .3) & $.573 * *$ & $389 * *$ & $.437^{* *}$ & $.542^{* *}$ \\
\hline & Empathy (X3.4) & $.628 * *$ & $.563 * *$ & $.553 * *$ & $.614^{* *}$ \\
\hline & Tangibles (X3.5) & $.578 * *$ & $414^{* *}$ & $.457^{* * *}$ & $.558 * *$ \\
\hline
\end{tabular}

1) From the analysis between these dimensions above, it could be concluded that the dimensions from brand image variable to the dimensions of customer satisfaction variable with the highest value was occured between trust (X1.2) on price (Y.2) with coefficient value of 0.426 meaning that it has moderate relationship.

2) From the analysis between the dimensions above, it can be concluded that the dimensions from sales promotion variable to dimensions of customer satisfaction variable who has the highest value was between marketing campaign (X2.1) on quality (Y.2) with coefficient value of 0.390 meaning that it has weak relationship.

3) From the analysis between the dimensions above, it could be concluded that dimensions from service quality variable to dimensions from customer satisfaction variable who has dominant influence was reliable dimension (X3.1) on Retail Image (Y.1) with coefficient value of 0.641 meaning that it has strong relationship. 
Table 10. Dimension Correlation Matrix on Customer Loyalty

\begin{tabular}{|c|c|c|c|c|c|c|}
\hline \multirow[b]{2}{*}{ XVariable } & \multirow[b]{2}{*}{ Dimension } & \multicolumn{5}{|c|}{ Z Variable } \\
\hline & & $\begin{array}{c}\text { Remain } \\
\text { L oyal } \\
(\mathrm{Z} .1)\end{array}$ & $\begin{array}{c}\text { Repurchase } \\
\text { the product } \\
(\mathrm{Z} .2)\end{array}$ & $\begin{array}{l}\text { Recommending } \\
\text { Product }(\mathrm{Z} .3)\end{array}$ & $\begin{array}{c}\text { Willingness } \\
\text { to pay more } \\
(\mathrm{Z} .4)\end{array}$ & $\begin{array}{c}\text { Owner } \\
\text { Right (Z.5) }\end{array}$ \\
\hline \multirow{3}{*}{$\begin{array}{l}\text { B rand Image } \\
\text { (X1) }\end{array}$} & Perception (X1.1) & $.384 * *$ & $.469 * *$ & $.452^{* * *}$ & $.465^{* *}$ & $.465 * *$ \\
\hline & Trust (X1.2) & $.344 * *$ & $.467 * *$ & $.460 * *$ & $.474^{* *}$ & $.474 * *$ \\
\hline & Association (X1.3) & $.262 * *$ & $.410 * *$ & $395^{* * *}$ & $.413 * *$ & $.413 * *$ \\
\hline \multirow{3}{*}{$\begin{array}{l}\text { Sales Promotion } \\
\text { (X2) }\end{array}$} & Sales Campaign (X2.1) & $.376^{* *}$ & $.524 * *$ & $.523 * *$ & $.540 * *$ & $.540 * *$ \\
\hline & Incentive Tools (X2.2) & $.337 * *$ & $.464^{* *}$ & $.479 * *$ & $.508 * *$ & $.508 * *$ \\
\hline & Certain Services (X2.3) & $.369 * *$ & $.511^{* *}$ & $.510^{* * *}$ & $.524 * *$ & $.524 * *$ \\
\hline \multirow{5}{*}{$\begin{array}{l}\text { Service Quality } \\
\text { (X3) }\end{array}$} & Reliability (X3.1) & $.593 * *$ & $.672 * *$ & $.692^{* * *}$ & $.657^{* *}$ & $.657 * *$ \\
\hline & Responsiveness (X3.2) & $.602 * *$ & $.676 * *$ & $.691^{* *}$ & $.653 * *$ & $.653 * *$ \\
\hline & Assurance (X3.3) & $.546^{* *}$ & $.571^{* *}$ & $.555^{* * *}$ & $.530 * *$ & $.530 * *$ \\
\hline & Empathy (X3.4) & $.600 * *$ & $.673^{* *}$ & $.690 * *$ & $.652^{* * *}$ & $.652 * *$ \\
\hline & Tangibles (X3.5) & $.506^{* *}$ & $.551^{* *}$ & $.526^{* * *}$ & $.505 * *$ & $.505 * *$ \\
\hline \multirow{4}{*}{$\begin{array}{c}\text { Customer } \\
\text { Satisfaction (Y) }\end{array}$} & Retail Image (Y.1) & $.476^{* *}$ & $.559 * *$ & $.562^{* * *}$ & $.522 * *$ & $.522 * *$ \\
\hline & Price (Y .2) & $.372^{* *}$ & $.572^{* *}$ & $.616^{* *}$ & $.576^{* *}$ & $.576 * *$ \\
\hline & Quality (Y .3) & $.478^{* *}$ & $.555^{* *}$ & $.599 * *$ & $.575^{* *}$ & $.575^{* *}$ \\
\hline & Product Performance (Y.2) & $.428 * *$ & $.463 * *$ & $.489 * *$ & $.437 * *$ & $.437 * *$ \\
\hline
\end{tabular}

1) From these relationship analysis between the dimensions above, it could be concluded that the dimensions from brand image variable on dimensions from customer loyalty variable which has highest value was the dimension of trust (X1.2) towards willingness to pay more (Z.4) with coefficient value of 0.474 meaning that it has fair connection.

2) From these relationship analysis between the dimensions above, it can be concluded that dimensions of sales promotion dimensions on customer loyalty dimensions which has the highest value was marketing campaign dimension (X2.1) towards willingness to pay more (Z.4) with coefficient value of 0.540 that means it has fair connection.

3) From the analysis of these relationship between the dimensions above, it could be concluded that the dimensions from service quality variable to the dimensions of customer loyalty variable who has dominant value was reliability (X3.1) towards recommending products (Z.3) with coefficient value of 0.692 which means that it has strong relationship.

4) From the analysis from these relationship between dimensions above, it could be concluded that the dimensions from customer satisfaction variable towards dimensions of customer loyalty variable who has highest value was the dimension of reliability (Y.2) against recommending products (Z.3) with coefficient value of 0.616 which means that it has strong relationship.

\section{Discussion}

Based on these research results, brand image had an impact on customer satisfaction. Kotler and Keller (2016:303) were explained that brand image could be describe the extrinsic nature of goods and services, including how brands try to meet the psychological or social needs of customers. According to Hawkin and Mothersbaugh (2010: 342) brand image refers to the schematic memory of a brand. It contains with target market's interpretation of attributes, benefits, usage situations, users and characteristics from producers/marketers. The results from this research were in line with prior research by Gedalia and Hartono (2015) which told that brand image had significant impact on customer satisfaction.

Based on these research results, its known that sales promotions had an impact towards customer satisfaction. Kotler and Keller (2016:519) which stated that sales promotion is a main material of marketing campaigns, consisting of a collection of incentive tools, mostly shortterm, designed to stimulate the faster or greater purchase of particular product or service by 
consumers or commerce. The results of this research were in line with prior research by Ali, et al (2018) which told that sales promotion had significant influence on customer satisfaction.

Based on these research results, it was known that service quality had an impact towards customer satisfaction. According to Grewal and Levy (2012:422), good service quality will results in satisfied and loyal customers. According to Kotler and Keller (2016:157), the impact from service quality could be describe as higher the quality level, the higher level of customer satisfaction. The results of this study are in line with previous research conducted by Kurniawan, et al (2020), Gunawan and Prasetyo (2020) that sales promotion had significant impact on customer satisfaction.

Based on these research results its known that customer satisfaction had influence on customer loyalty. According to Kotler and Keller (2016:478) marketing communication activities contribute to brand equity and drive sales in many ways: by creating brand awareness, build a brand images in consumer memories, generating positive brand judgments or feelings and strengthening the consumer loyalty. The results from this research were in line with prior research by Tiasanty and Sitio (2019) which told that customer satisfaction had significant impact towards customer loyalty.

The results showed that brand image had positive and significant impact on customer loyalty with customer satisfaction as an intervening variable. Customer satisfaction is an overall assessment from consumption experience. This had positive evaluation after consumption behavior. This may be an evaluation of either the consumption process or the outcome from consumption. The results from this research were in line with prior research by Kurniawati, et al (2014) which defined that brand image had significant impact on customer loyalty with customer satisfaction as an intervening variable.

The results showed that sales promotion had positive and significant impact on customer loyalty with customer satisfaction as an intervening variable. According to Kotler and Keller (2016:774) sellers use incentive-type promotions to attract new users, to reward loyal customers and increase the rate of occasional (rare) user repurchases. The results were in line with prior research by Tjahjaningsih (2013) which defined that sales promotion had significant impact on customer loyalty with customer satisfaction as intervening variable.

The results showed that service quality had positive and significant influence on customer loyalty with customer satisfaction as an intervening variable. According to Kotler and Keller (2016:157) the influence from service quality like the higher quality level, the higher level of customer satisfaction will achieved. According to Grewal and Levy (2012:422) good service quality will results in satisfied and loyal customers. These results were in line with prior research by Prayoga, et al (2014) which defined that service quality had significant impact on customer loyalty with customer satisfaction as an intervening variable.

\section{CONCLUSION AND SUGGESTION Conclusion}

Based on these research results, there has several conclusions from this research which could be drawn as follows: 
1) Brand image had positive and significant impact towards customer satisfaction.

2) Sales promotion had positive and significant impact on customer satisfaction.

3) Service quality had positive and significant impact towards customer satisfaction.

4) These research results was indicated that customer satisfaction had positive and significant impact on customer loyalty.

5) These research results was indicated that brand image had positive and significant influence over customer loyalty.

6) The results showed that sales promotion had positive and significant impact on customer loyalty.

7) The results showed that service quality had positive and significant impact on customer loyalty.

\section{Suggestion}

Based on these research results and those several conclusions, here the suggestions that could be advise from this research such as:

1) Based on these research results, its known that the Association Dimension (X1.3) has the lowest average value compared to other dimensions in Brand Image Variable (X1). Therefore, the authors suggest that X Department Store need further improve on brand association with consumer habits, values and lifestyles related to fashion trends, so the consumers could relate with current fashion trend and would have a good memory towards X Department Store .

2) Based on these research results, its known that the Incentive tools Dimension (X2.2) has the lowest average value compared to other dimensions in Sales Promotion Variable (X2). Therefore, the authors were suggest that X Department Store need to provide more benefits for incentive tools, could be in form of shopping vouchers, purchase with purchases or spending points rewards on membership cards as of next purchase, consumers could use the incentive tools to get better benefits from X Department Store.

\section{REFERENCES}

Ali, H., Narulita, E., \& Nurmahdi, A. (2018). The Influence of Service Quality, Brand Image and Promotion on Purchase Decision at MCU Eka Hospital. Saudi Journal of Business and Management Studies, 3(1): 88-97.

Gedalia, C.C., \& Hartono S. (2015). Pengaruh Kualitas Layanan dan Brand Image terhadap Loyalitas Konsumen dengan Kepuasan Konsumen sebagai Variabel Intervening (Studi Kasus Monopole Coffee Lab Surabaya). Jurnal Manajemen Pemasaran Petra, 3(1): 110.

Gunawan, H., \& Prasetyo, J.H. (2020). The Influence of Service Quality towards the Customer Satisfaction of XYZ Bank at Gajah Mada Branch Office in West Jakarta. International Journal of Innovative Science and Research Technology, Vol. 5, Issue 3.

Hawkins, D.I., \& Mothersbaugh, D.L. (2010), Consumer Behavior: Building Marketing Strategy.11th edition. USA: McGraw-Hill, Irwin 
Kotler, P., \& Armstrong, G. (2014). Principles of Marketing, 15 ${ }^{\text {th }}$ Edition, US: Pearson Education Inc.

Kotler, P., \& Kevin L.K. (2016). Marketing Management, 15th Edition. USA: Pearson Education Inc.

Kurniawan, M.R., Utami, H.R., \& Prasetyo, J.P. (2020). The reaction towards Customer Satisfaction through the Service Quality Variable at Foreign Private Banks in Jakarta Headquarter. International Journal of Innovative Science and Research Technology, Vol. 5, Issue 3.

Kurniawati, D., Suharyono., \& Andriani, K. (2014). Pengaruh Citra Merek dan Kualitas Produk terhadap Kepuasan dan Loyalitas Pelanggan (Studi pada Pelanggan KFC Cabang Kawi Malang). Jurnal Administrasi Bisnis, 14(2): 1-9.

Levy, M., \& Weitz, B. A. (2012). Retailing Management Information Center. New York: McGraw Hill Higher Education.

Prayoga, B.P., Made W.K., \& Alit, S. (2014). Pengaruh Kualitas Pelayanan Terhadap Kepuasan dan Loyalitas Pelanggan pada Ramayana Department Store di Kota Denpasar. Jurnal Manajemen Unud, 5(2): 1-19.

Rath, Patricia M., Bay, S., Petrizzi, R., \& Gill, P. (2015) Consumer Behavior And Fashion Marketing. $2^{\text {nd }}$ edition. US: Bloomsbury Publishing Inc.

Tiasanty, L., \& Sitio, A. (2019). Analysis of the Effect of Service Quality, Product Quality and Brand Image on Customer Satisfaction and Its Implications on Consumer Loyalty PT. Sharp Electronics Indonesia (Case Study at Karawang Sharp Direct Service Station). International Journal of Engineering Technologies and Management Research, 6(1).

Tjahjaningsih, E. (2013). Pengaruh Citra dan Promosi terhadap Kepuasan Pelanggan serta Dampaknya terhadap Loyalitas Pelanggan (Studi pada Pelanggan Supermarket Carrefour di Semarang). Media Ekonomi Manajemen, 28(2): 13-27. 